\title{
Effects of $\beta$-k-casein (CSN2-CSN3) haplotypes and $\beta$-lactoglobulin (BLG) genotypes on milk production traits and detailed protein composition of individual milk of Simmental cows
}

\author{
V. Bonfatti, ${ }^{* 1}$ G. Di Martino, ${ }^{*}$ A. Cecchinato, ${ }^{*}$ D. Vicario,† and P. Carnier* \\ *Department of Animal Science, University of Padova, viale dell'Università 16, 35020, Legnaro, Padova, Italy \\ †Italian Simmental Cattle Breeders Association, via Nievo 19, 33100, Udine, Italy
}

\begin{abstract}
The aim of this study was to investigate the effects of CSN2-CSN3 ( $\beta$-к-casein) haplotypes and $B L G$ ( $\beta$-lactoglobulin) genotypes on milk production traits, content of protein fractions, and detailed protein composition of individual milk of Simmental cows. Content of the major protein fractions was measured by reversedphase HPLC in individual milk samples of 2,167 cows. Protein composition was measured as percentage of each casein $(\mathrm{CN})$ fraction to total $\mathrm{CN}$ and as percentage of $\beta$-lactoglobulin ( $\beta$-LG) to total whey protein. Genotypes at $C S N 2, C S N 3$, and $B L G$ were ascertained by reversed-phase HPLC, and CSN2-CSN3 haplotype probabilities were estimated for each cow. Traits were analyzed by using a linear model including the fixed effects of herd-test-day, parity, days in milk, and somatic cell score class, linear regressions on haplotype probabilities, class of $B L G$ genotype, and the random effect of the sire of the cow. Effects of haplotypes and $B L G$ genotypes on yields were weak or trivial. Genotype BB at $B L G$ and haplotypes carrying CSN2 B and CSN3 B were associated with increased CN content and $\mathrm{CN}$ number. Haplotypes including CSN3 B were associated with increased $\kappa$-CN content and percentage of $\kappa-\mathrm{CN}$ to total $\mathrm{CN}$ and with decreased percentages of $\alpha_{S^{-}}$and $\gamma$-CN to total CN. Allele CSN2 B had the effect of increasing $\beta$-CN content and decreasing content of $\alpha_{\mathrm{S}_{1}} \mathrm{CN}$. Haplotypes including allele CSN2 $\mathrm{A}^{1}$ exhibited decreased $\beta-, \alpha_{\mathrm{S}^{-}}$, and $\gamma$-CN concentrations and increased $\alpha_{\mathrm{S}^{-}}$and $\kappa^{-} \mathrm{CN}$ contents, whereas CSN2 I had positive effects on $\beta$-CN concentration and trivial effects on content of other protein fractions. Effects of haplotypes on $\mathrm{CN}$ composition were similar to those exerted on content of $\mathrm{CN}$ fractions. Allele $B L G$ $A$ was associated with increased $\beta$-LG concentration and percentage of $\beta$-LG to total whey protein and with decreased content of other milk proteins, namely $\beta$-CN
\end{abstract}

Received September 29, 2009.

Accepted April 8, 2010.

${ }^{1}$ Corresponding author: valentina.bonfatti@unipd.it and $\alpha_{\mathrm{S}^{-}} \mathrm{CN}$. Estimated additive genetic variance for investigated traits ranged from 14 to $39 \%$ of total variance. Increasing the frequency of specific genotypes or haplotypes by selective breeding might be an effective way to change milk protein composition.

Key words: casein haplotypes, $B L G$ genotype, milk protein composition, Simmental

\section{INTRODUCTION}

Most research concerning milk protein polymorphisms has focused on the associations of CSN3 $(\kappa-\mathrm{CN})$ and $B L G(\beta-\mathrm{LG})$ polymorphisms with milk production traits, coagulation time, curd firmness, and cheese yield. Results of studies (Braunschweig et al., 2000; Ikonen et al., 2001; Boettcher et al., 2004a) investigating effects of single protein genes on production traits have not been consistent, but associations of CSN3 B with enhanced milk coagulation properties (Schaar, 1984) and increased cheese yields (Schaar et al., 1985; Aleandri et al., 1990) have been consistently reported.

A role of milk protein composition in variation of coagulation properties has been recently described (Wedholm et al., 2006; Jõudo et al., 2008). A few studies have investigated associations of milk protein polymorphisms with protein composition and examined mostly the effects of $C S N 3$ and $B L G$ genes. Significant effects of $B L G$ and $C S N 3$ genes on concentrations of $\beta$-LG, $\kappa-\mathrm{CN}$, and total $\mathrm{CN}$ in milk have been reported (Lunden et al., 1997; Mayer et al., 1997; Robitaille et al., 2002), and linked polymorphisms in the noncoding regions of these genes have been assumed to affect transcription of milk proteins (Martin et al., 2002). Variation in CN composition has been related to effects of CSN2 ( $\beta$ CN) variants (Heck et al., 2009), but knowledge on the association of CSN2 B with CN composition is scarce because CSN2 B is found at low frequency in all previously investigated cattle populations.

Because simultaneous quantification of all major proteins is difficult, the effects of single genes on concentration or relative ratios of major protein fractions have been investigated using limited numbers of animals 
(Bobe et al., 1999; Hallén et al., 2008). Genotype effects have been considered in all those studies. Recently, for the first time, the effects exerted by $\mathrm{CN}$ haplotypes on milk protein composition have been investigated using a large sample of Dutch Holstein-Friesian cows (Heck et al., 2009). Genes encoding $\alpha_{\mathrm{S}_{1}} \mathrm{CN}, \alpha_{\mathrm{S2} 2} \mathrm{CN}, \beta-\mathrm{CN}$, and $\mathrm{\kappa}-\mathrm{CN}$ are located on chromosome 6 , within a region of about $250 \mathrm{~kb}$ (Ferretti et al., 1990; Threadgill and Womack, 1990). This makes it difficult to assess single CN gene effects (Lien et al., 1995) and preferable to estimate CN haplotype effects instead of genotype effects (Ikonen et al., 2001; Boettcher et al., 2004a).

With few exceptions (Bobe et al., 1999; Heck et al., 2009), estimation of milk protein polymorphism effects on detailed protein composition has been performed using ordinary least squares procedures, and effects due to polygenes have been ignored. Consequently, estimated effects of milk protein loci might be biased (Kennedy et al., 1992).

Only a few studies have been carried out on variation of milk protein composition in Simmental cows (PérezRodríguez et al., 1998; Amigo et al., 2001; Graml and Pirchner, 2003), although Simmental cattle populations are present in many countries. If compared with other breeds, where frequency of some alleles (e.g., CSN3 B or CSN2 B) is very high or very low, the Simmental breed exhibits more equilibrated allelic frequencies at milk protein genes. This facilitates the estimation of haplotype and genotype effects. Moreover, this breed exhibits a moderate presence of allele CSN2 I, whose effects have never been reported previously.

The aim of this study was to estimate the effects exerted by $\mathrm{CN}$ haplotypes and $B L G$ genotypes on milk production traits, protein fraction contents, and detailed milk protein composition in individual milk samples of Italian Simmental cows.

\section{MATERIALS AND METHODS}

\section{Animals and Milk Sampling}

Individual milk samples of 2,167 Simmental cows, reared in 47 commercial herds in the north of Italy, were collected from November 2007 to December 2008. Milk sampling occurred once per animal, during the morning or evening milking, concurrently with the monthly milk recording of the herd. Herd and test-day effects were confounded because all cows of a herd were sampled on the same test day.

Preservative (Bronopol, 0.6:100 vol/vol, Grunenthal Prodotti \& Farmaceutici Formenti, Milan, Italy) was added to milk immediately after collection to prevent microbial growth and stored at $-40^{\circ} \mathrm{C}$ until reversedphase (RP) HPLC analysis to prevent enzymatic proteolysis. The Italian Simmental cattle breeders' association (ANAPRI, Udine, Italy) provided pedigree information and measures of milk yield and fat and protein content collected in the national milk recording program. In the national milk recording program, milk fat and protein content are determined using midinfrared spectroscopy and a Fourier transformed interferogram (MilkoScan FT 6000, Foss Electric, Hillerød, Denmark).

\section{Milk Protein Composition and Genotyping}

Contents of $\alpha_{\mathrm{S}^{-}} \mathrm{CN}, \alpha_{\mathrm{S} 2}-\mathrm{CN}, \beta-\mathrm{CN}, \gamma-\mathrm{CN}, \kappa-\mathrm{CN}$, $\beta-\mathrm{LG}$, and $\alpha$-LA of individual milk samples were measured using the RP-HPLC method proposed by Bonfatti et al. (2008). Genotypes of cows for CSN2, $C S N 3$, and $B L G$ were also determined by RP-HPLC. Briefly, the method separates the major $\mathrm{CN}$ and whey protein fractions in one run at very high resolution and provides quantification of content of $\mathrm{A}^{1}, \mathrm{~A}^{2}, \mathrm{~B}$, and I variants of $\beta-\mathrm{CN}, \mathrm{A}$ and $\mathrm{B}$ variants of $\kappa-\mathrm{CN}$, and $\mathrm{A}$, $\mathrm{B}$, and $\mathrm{D}$ variants of $\beta$-LG. When analyzing individual milk samples of homozygous animals, a whole-protein fraction contains a single genetic variant and RP-HPLC quantification can be affected by the response factor of the specific protein form. Because purified protein genetic variants were used to develop specific calibration equations, the method used in this study was suitable for the quantification of protein fraction contents in individual milk samples. A detailed description of the RP-HPLC technique used in this study can be found in Bonfatti et al. (2008).

Because the frequency of $B L G \mathrm{D}$ was very low, records of cows carrying this allele were not considered in the statistical analysis. The RP-HPLC method did not differentiate CSN1S1 $\left(\alpha_{\mathrm{S} 1}-\mathrm{CN}\right)$ alleles. Because the frequency of the $\mathrm{C}$ allele at CSN1S1 has been reported to range from 0.08 to 0.11 for Simmental cattle (PérezRodríguez et al., 1998; Jann et al., 2004), suitability of alternative genotyping techniques was carefully evaluated in terms of benefits and disadvantages. This involved the assessment of genotypes at CSN1S1 in a random sample of 200 cows by direct DNA sequencing. A portion of exon 17 of CSN1S1 (allele B and C discriminating fragment) was amplified by standard PCR using primers Csn1S1_ex17f 5'-TGGATGCCTATCCATCTGGT-3' and Csn1S1_ex17r 5'-CACTGCTCCACATGTTCCTG-3'. Amplicons (333 bp) were directly sequenced using the Csn1S1_ex17f primer on a CEQ8000 sequencer (BeckmanCoulter, Fullerton, CA). Because the frequency of CSN1S1 C was $<6 \%$ in the investigated sample, genotyping through direct DNA sequencing was not extended to all milk samples, and the CSN1S1 gene was not considered when defining 
CN haplotypes. With such a low frequency, haplotypes carrying CSN1S1 C would have been likely included in the group of "rare" haplotypes or would have obtained a trivial haplotype probability, thus limiting the reliability of the estimated haplotype effects. However, the omission of CSN1S1 C from CN haplotype definition might have introduced a bias in the estimation of haplotype effects.

The frequency of CSN3 E (which could not be differentiated from CSN3 A by RP-HPLC) is known to be quite low in Simmental cattle populations, ranging from 4\% for Czech Simmental (Matějíček et al., 2008) to 0\% for Italian Simmental (Jann et al., 2004), although this allele has been detected with greater frequency in other cattle breeds (Ikonen et al., 1999a; Heck et al., 2009). Because of its low frequency, no assessment of the frequency of CSN3 E by direct DNA sequencing was performed in the investigated sample. Hence, the estimated effects of CSN3 A might be slightly biased, being, for a small number of samples, the combined effects of $C S N 3 \mathrm{~A}$ and $\mathrm{E}$ variants.

Despite the partial co-elution of $\beta-\mathrm{CN}$ I with $\mathrm{A}^{2}$ variant, the double peak of heterozygous $\mathrm{A}^{2} \mathrm{I}$ samples exhibited a typical shape, making identification of genotype $\mathrm{A}^{2} \mathrm{I}$ straightforward. Also, heterozygous $\mathrm{A}^{1} \mathrm{I}$ and BI samples exhibited a characteristic shape of the valley between $\beta-\mathrm{CN}$ peaks so that genotyping errors were unlikely. Shifts of the chromatogram were rare and usually homogeneous in the whole $\beta$-CN elution interval. Of course, genotyping errors, albeit unlikely, might have occurred for homozygous $\mathrm{A}^{2} \mathrm{~A}^{2}$ and II samples.

Fraction $\gamma$-CN consisted of several minor peaks eluting close to the $\beta$-CN elution interval or partially co-eluting with $\beta$-CN. Although $\gamma-\mathrm{CN}$ consisted of multiple peaks exhibiting low resolution, content of this fraction was quantified with good repeatability and reproducibility, similar to that ascertained by Bonfatti et al. (2008) for other protein fractions, and provided an indication on the extent of proteolysis occurring in milk samples. Repeatability, measured as relative standard deviation of peak areas assessed in 10 consecutive injections of the same milk sample, was $2.57 \%$, whereas reproducibility, measured as relative standard deviation of peak areas in a sequence of 10 individual milk samples injected over $4 \mathrm{~d}$, was $3.42 \%$.

\section{Trait Definitions}

For proteins quantified by RP-HPLC, total CN (TCN, g/L) was computed as the sum of $\alpha_{\mathrm{S}_{1}-\mathrm{CN}}$, $\alpha_{\mathrm{S} 2}-\mathrm{CN}, \beta-\mathrm{CN}, \gamma-\mathrm{CN}$, and $\kappa-\mathrm{CN}$ content in milk. Total whey protein $(\mathbf{W H}, \mathrm{g} / \mathrm{L})$ was calculated as the sum of $\alpha-\mathrm{LA}$ and $\beta$-LG content. Total protein (PRT, g/L) was computed as the sum of TCN and WH. Casein number (\%) was calculated as the percentage ratio of TCN to PRT. Protein composition (i.e., relative content of protein fractions) was computed as percentage of $\alpha_{\mathrm{S}_{1}}-\mathrm{CN}$, $\alpha_{\mathrm{S} 2}-\mathrm{CN}, \beta-\mathrm{CN}, \gamma-\mathrm{CN}$, and $\kappa-\mathrm{CN}$ to TCN and as the percentage of $\beta$-LG to WH. When protein composition is measured as percentage ratio of each fraction to PRT, for haplotypes associated with increased casein number, the percentage ratios of all $\mathrm{CN}$ fractions are expected to increase, whereas those of whey fractions are expected to decrease. Use of percentage ratios of each CN fraction to TCN, or of each whey fraction to $\mathrm{WH}$, ensures that estimation of haplotype effects on protein composition is not affected by concurrent variation in casein number.

\section{Computation of Haplotype Probabilities}

Sire families of limited size are rather common in the Italian Simmental population. For $60 \%$ of the sires, family size was between 2 and 5 daughters, for $17.2 \%$ was between 6 and 20 daughters, and for $10.4 \%$ between 21 and 50 daughters. Only $3 \%$ of the sires had more than 50 daughters. Because sire genotypes were unknown, but also to avoid problems related to the attribution of haplotypes in families of very small size that would have markedly reduced the size of the data set, we estimated haplotype probabilities. Cows $(2,016$ animals) originating from sires with at least 2 genotyped daughters were used to estimate CSN2-CSN3 haplotype probabilities. Two animals had genotypes that were incompatible with observed haplotypes in their families and were discarded. The probability of haplotypes inherited by each daughter was estimated using the method proposed by Boettcher et al. (2004b). When computing haplotype probabilities, no recombination across CN genes was assumed. The expected number of copies of each possible haplotype carried by an animal was indirectly derived from the estimated probabilities. To test the null hypothesis that genotypes at one locus were independent of genotypes at another locus (i.e., to test the hypothesis of linkage equilibrium between loci), GenePop Version 4.0 (http://kimura.univmontp2. $\mathrm{fr} / \sim$ rousset/Genepop.htm) was used. The program creates contingency tables for all pairs of genes and then performs a probability test for each table using a Monte Carlo Markov chain method. Hardy-Weinberg equilibrium was also verified for each locus by using a Monte Carlo Markov chain method. Values of $\mathrm{r}^{2}$ for haplotypes including $C S N 3$ and $B L G$ were computed following the method proposed by Hill and Robertson (1968) and Zhao et al. (2005), and used by Heck et al. (2009). 


\section{Statistical Analysis}

The effects of $\mathrm{CN}$ haplotypes and $B L G$ genotypes on phenotypic variation of milk production traits, and content and percentage of protein fractions were estimated using a linear mixed model with the MIXED procedure of SAS (Version 9.1, SAS Institute Inc., Cary, NC). The mixed model was

$$
\begin{aligned}
\mathrm{y}_{i j k l m n o} & =\mathrm{HTD}_{i}+\mathrm{P}_{j}+\mathrm{DIM}_{k}+\mathrm{SCS}_{l} \\
& +\sum_{\mathrm{s}=1}^{h} \beta_{\mathrm{s}} \mathrm{PR}_{\mathrm{s}: \mathrm{ijklmno}}+\mathrm{BLG}_{m}+\text { sire }_{n}+\mathrm{e}_{i j k l m n o},
\end{aligned}
$$

where $\mathrm{y}_{i j k l m n o}$ is a measure for a trait; $\mathrm{HTD}_{i}$ is the fixed effect of herd-test day $i(i=1, \ldots, 47) ; \mathrm{P}_{j}$ is the fixed effect of parity $j$ of the cow $(j=1$ : first parity, $j=2$ : second parity, $j=3$ : third parity, $j=4$ : fourth and later parities); $\mathrm{DIM}_{k}$ is the fixed effect of DIM class $k$ (12 classes of 30-d intervals, with the exception of the last class, which included samples collected at DIM 330 or greater); $\mathrm{SCS}_{l}$ is the fixed effect of SCS computed as $\log _{2}\left(\mathrm{SCC} \times 10^{3}\right)+3(6$ classes of 1 -point interval, with the exception of the last class, which included records with SCS $\geq 5) ; h$ is the total number of haplotypes evaluated $(h=8)$; $\mathrm{PR}_{\mathrm{s}: \mathrm{j} j \mathrm{klm} n}$ is the probability that the cow carried haplotype s, expressed as the expected number of copies of haplotype s carried by the animal; $\beta_{\mathrm{s}}$ is the regression coefficient on the probability of haplotype s; $\mathrm{BLG}_{m}$ is the fixed effect of $B L G$ genotype class $m(m=1: \mathrm{AA}, m=2: \mathrm{AB}, m=3: \mathrm{BB}) ;$ sire $_{n}$ is the random effect of the sire of the cow $(n=1, \ldots, 211)$ assumed to follow a normal distribution with sire $_{n} \sim N\left(\mathbf{0}, \mathbf{A} \sigma_{s}^{2}\right)$, where $\sigma_{s}^{2}$ is the sire variance and $\mathbf{A}$ is the additive relationship matrix among sires; and $\mathrm{e}_{i j k l m n o}$ is a random residual assumed to follow a normal distribution with $\mathrm{e}_{i j k l m n o} \sim N\left(0, \sigma_{e}^{2}\right)$, where $\sigma_{e}^{2}$ is the residual variance.

A probability (ranging from 0 to 1 ) was assigned to each possible haplotype carried by an animal. For example, if 2 copies of the same haplotype composed the only possible haplotype couple, that haplotype gained a final value of 2 because the animal was expected to carry 2 copies of the haplotype, each with a probability of 1 . The difference between the regression coefficients for 2 haplotypes of interest estimates the expected change in the phenotype of a given trait when a copy of the second haplotype replaces a copy of the first haplotype. Likewise, in the hypothetical situation in which 2 animals differ by one haplotype only, the difference between the estimated coefficients would correspond to the expected difference in the phenotype of the 2 animals for a given trait (Boettcher et al., 2004a). Only additive effects of haplotypes were estimated and dominance effects were not considered. Sire effects were included in the model to account for variation due to polygenes underlying the investigated traits. Although there were multiple daughter records per sire taken at different stages of lactation, a random regression model was not applicable because most sire families were of limited size.

\section{RESULTS AND DISCUSSION}

\section{Descriptive Statistics}

Descriptive statistics for the investigated traits are reported in Table 1. The difference between average protein content assessed in the national milk recording program and average protein content measured by RP-HPLC was large. This must be ascribed to the skimming of milk before chromatographic analysis and to the specific gravity of milk. Indeed, protein content assessed by HPLC was measured in weight per volume whereas protein content, quantified in the milk recording program, was measured in weight per weight. After adjusting measures for skimming and specific gravity of milk, averages of the 2 traits were comparable. Because measures of protein content provided by mid-infrared spectroscopy are predictions of $\mathrm{CP}$ content (including the NPN fraction), higher values are to be expected compared with RP-HPLC assessment (which does not include NPN and minor protein fractions). Nevertheless, RP-HPLC protein content was consistently greater than measures obtained in the national milk recording program. This is attributable to more favorable preservation conditions ensured for samples analyzed by RP-HPLC than for samples collected in the milk recording program, and differences increased in summer, when preservation of samples is more critical (data not shown). Pearson product-moment correlation between measures of milk protein content provided by RP-HPLC and those obtained in the milk recording program was 0.77 .

Because of lack of NPN and minor serum proteins, high values of casein number, ranging from 84 to $91 \%$, were observed. This was in agreement with results reported by Heck et al. (2009), who used capillary electrophoresis for the analysis of individual milk samples of Dutch Holstein-Friesian cows.

\section{Alleles and Haplotype Frequencies}

Genotype and allele frequencies for CSN2, CSN3, and $B L G$ are presented in Table 2. To our knowledge, this is the first time that such frequencies are computed based on a large sample of Simmental cows. Four alleles $\left(\mathrm{A}^{1}\right.$, $\mathrm{A}^{2}, \mathrm{~B}$, and $\mathrm{I}$ ) for $C S N 2,2$ alleles $(\mathrm{A}$ and $\mathrm{B})$ for $C S N 3$, 
Table 1. Descriptive statistics for milk production traits, protein fraction contents, and protein composition $(\mathrm{n}=2,167)$

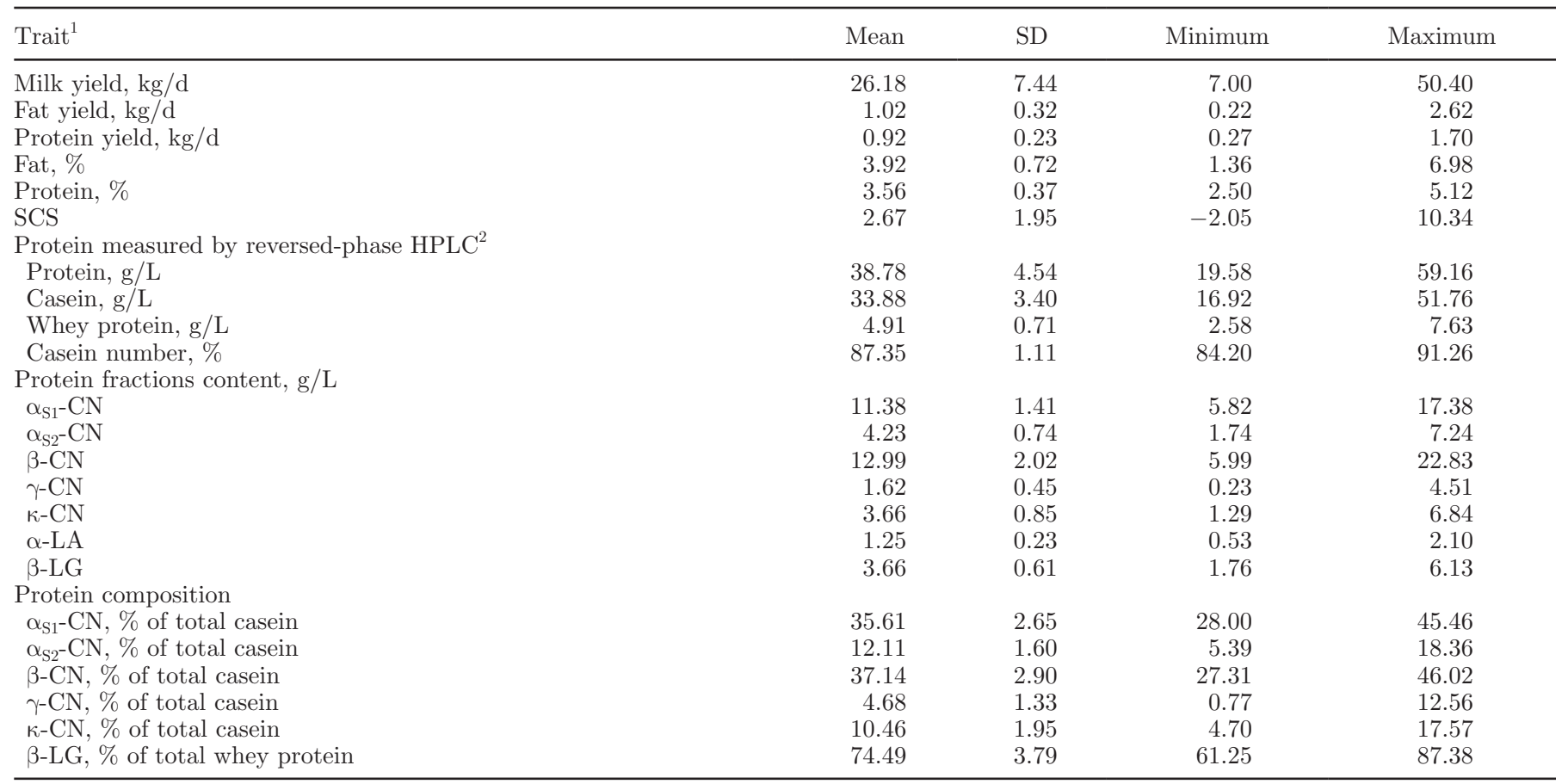

${ }^{1} \mathrm{SCS}=\log _{2}\left(\mathrm{SCC} \times 10^{3}\right)+3$; casein $=\alpha_{\mathrm{S}_{1}-\mathrm{CN}}+\alpha_{\mathrm{S}^{2}} \mathrm{CN}+\beta-\mathrm{CN}+\gamma-\mathrm{CN}+\kappa$-CN; whey protein $=\beta$-LG $+\alpha-\mathrm{LA} ;$ protein $=$ casein + whey protein; casein number $=(\mathrm{CN} /$ protein $) \times 100$.

${ }^{2}$ Contents of all protein fractions were measured by reversed-phase HPLC on skim milk.

and 3 alleles (A, B, and D) for $B L G$ were present in the sampled population. Nevertheless, milk proteins in bovine species are affected by the presence of many genetic variants (Caroli et al., 2009), which may create further hidden variability.

Unlike other breeds in which some alleles at $\mathrm{CN}$ loci have very high or very low frequencies, balanced allele frequencies were detected at all investigated loci, particularly at CSN2 where the B allele showed a moderate frequency (0.16). With the exception of CSN2 I, allele frequencies were in good agreement with those reported by Jann et al. (2004) for a sample of Simmental cows of limited size. Almost 30\% of animals carried at least one copy of CSN2 B, and the frequency of CSN3 BB

Table 2. Genotype and allele frequencies for CSN2 ( $\beta-\mathrm{CN}), C S N 3$ ( $\kappa-\mathrm{CN})$, and BLG ( $\beta-\mathrm{LG})$ loci $(\mathrm{n}=2,167)$

\begin{tabular}{|c|c|c|c|c|}
\hline \multirow[b]{2}{*}{ Locus } & \multicolumn{2}{|c|}{ Genotype frequency } & \multicolumn{2}{|c|}{ Allele frequency } \\
\hline & Genotype & Frequency & Allele & Frequency \\
\hline \multirow[t]{10}{*}{ CSN2 } & $\mathrm{A}^{2} \mathrm{~A}^{2}$ & 0.362 & $\mathrm{~A}^{2}$ & 0.596 \\
\hline & $\mathrm{A}^{1} \mathrm{~A}^{2}$ & 0.224 & $\mathrm{~A}^{1}$ & 0.188 \\
\hline & $\mathrm{A}^{2} \mathrm{~B}$ & 0.177 & B & 0.158 \\
\hline & $\mathrm{A}^{1} \mathrm{~B}$ & 0.065 & $\mathrm{I}$ & 0.058 \\
\hline & $\mathrm{A}^{2} \mathrm{I}$ & 0.064 & & \\
\hline & $\mathrm{A}^{1} \mathrm{~A}^{1}$ & 0.036 & & \\
\hline & BB & 0.025 & & \\
\hline & BI & 0.022 & & \\
\hline & $\mathrm{A}^{1} \mathrm{I}$ & 0.019 & & \\
\hline & II & 0.006 & & \\
\hline \multirow[t]{3}{*}{ CSN3 } & AA & 0.438 & A & 0.652 \\
\hline & $\mathrm{AB}$ & 0.432 & B & 0.348 \\
\hline & BB & 0.130 & & \\
\hline \multirow[t]{5}{*}{$B L G$} & $\mathrm{AB}$ & 0.466 & A & 0.543 \\
\hline & AA & 0.306 & B & 0.449 \\
\hline & BB & 0.213 & $\mathrm{D}$ & 0.008 \\
\hline & $\mathrm{AD}$ & 0.008 & & \\
\hline & $\mathrm{BD}$ & 0.007 & & \\
\hline
\end{tabular}


Table 3. Frequency of CSN2-CSN3 $(\beta-\kappa-\mathrm{CN})$ haplotypes $(\mathrm{n}=2,016)$

\begin{tabular}{lc}
\hline Haplotype & Frequency \\
\hline $\mathrm{A}^{2} \mathrm{~A}$ & 0.387 \\
$\mathrm{~A}^{2} \mathrm{~B}$ & 0.207 \\
$\mathrm{~A}^{1} \mathrm{~A}$ & 0.128 \\
$\mathrm{~A}^{1} \mathrm{~B}$ & 0.059 \\
$\mathrm{BA}$ & 0.119 \\
$\mathrm{BB}$ & 0.040 \\
$\mathrm{IA}$ & 0.016 \\
$\mathrm{IB}$ & 0.043 \\
\hline
\end{tabular}

animals $(\mathrm{n}=282)$ was rather high. Within the studied genes, only CSN2 was in Hardy-Weinberg equilibrium $(P>0.05)$.

Similar to results for other breeds (Ikonen et al., 2001; Boettcher et al., 2004a), linkage disequilibrium between $C S N 2$ and $C S N 3$ genes was detected $(P<0.001)$. Following haplotype reconstruction, 8 CSN2-CSN3 haplotypes, including all combinations between $C S N 2$ and CSN3 alleles, were identified. Haplotypes were assigned with a probability of 1 to 1,493 cows (i.e., $74 \%$ of the total). Haplotype frequencies (Table 3) were calculated as the weighted mean of haplotype probabilities; thus, all the animals were included in the computation. The most frequent CSN2-CSN3 haplotype was $\mathrm{A}^{2} \mathrm{~A}$ that had a frequency of $39 \%$. Haplotypes carrying allele CSN2 B had a moderate frequency, whereas the rarest haplotype was IA with a frequency of $1.6 \%$.

Linkage disequilibrium was also detected $(P<0.001)$ between $C S N 3$ and $B L G$, which are located on different chromosomes, and might be due to random drift. To quantify linkage disequilibrium, the coefficient of determination $\left(\mathrm{r}^{2}\right)$ of the $C S N 3$ and $B L G$ variants, as described by Hill and Robertson (1968), was computed. Despite the statistically significant linkage disequilibrium, the overall $\mathrm{r}^{2}$ for haplotypes including $C S N 3$ and $B L G$ was $<0.006$.

\section{Effect of CN Haplotypes and BLG Genotypes on Milk Production Traits}

Estimated effects exerted by $\mathrm{CN}$ haplotypes and additive and dominance deviations at $B L G$ for milk production traits are reported in Tables 4 and 5, respectively. All estimated effects are measured in standard deviation units of the trait to make across-trait comparisons easy. With few exceptions, milk, fat, and protein yield, and fat and protein content were not affected by $\mathrm{CN}$ haplotypes or by $B L G$ genotypes. In comparison with results for haplotype $\mathrm{A}^{2} \mathrm{~A}$, slight increases $(P<0.05)$ of fat and protein content and protein yield were observed in the presence of haplotype $\mathrm{A}^{1} \mathrm{~A}$, and a slight increase $(P<0.05)$ of protein content was associated with haplotypes $\mathrm{A}^{2} \mathrm{~B}$ and IB. These results do not agree with those obtained by Boettcher et al. (2004a) for Italian Holstein-Friesian and Brown Swiss cows. Those authors reported an important effect of CSN1S1 C on milk protein content. Hence, negligible effects of CN haplotypes on protein content obtained in our study might be ascribed to missing information on CSN1S1 C.

With the exception of the CSN3 effect on protein content, results concerning effects of $\mathrm{CN}$ genes on milk production traits are not consistent across studies and breeds (Braunschweig et al., 2000; Ikonen et al., 2001; Boettcher et al., 2004a). Bovenhuis et al. (1992) suggested that associations between $\mathrm{CN}$ genes and milk production traits are attributable to effects of linked loci and not to direct effects of milk protein genes. Under this assumption, associations between milk protein genes and linked QTL might differ across breeds and sire families and might explain inconsistencies across studies. Possible QTL might be located in noncoding regions (i.e., promoter regions), which are known to play a role in protein expression, as well as at different positions on BTA6 such as $O P N$ or $A B C G 2$, which have

Table 4. Estimated effects $( \pm \mathrm{SE})$ of CSN2-CSN3 $(\beta-\kappa-\mathrm{CN})$ haplotypes compared with haplotype $\mathrm{A}^{2} \mathrm{~A}$ on milk, protein, and fat daily yield, and fat and protein content (magnitude of effects is expressed in SD units of traits $)^{1}$

\begin{tabular}{lcrccc}
\hline Haplotype & Milk yield & Protein yield & Fat yield & Protein content & Fat content \\
\hline $\mathrm{A}^{2} \mathrm{~A}$ & 0 & 0 & 0 & 0 & 0 \\
$\mathrm{~A}^{1} \mathrm{~A}$ & $-0.022 \pm 0.041$ & $-0.003 \pm 0.045$ & $0.046 \pm 0.047$ & $0.093 \pm 0.042^{*}$ & $0.110 \pm 0.051^{*}$ \\
$\mathrm{BA}$ & $0.070 \pm 0.043$ & $0.069 \pm 0.047$ & $0.097 \pm 0.049 \dagger$ & $0.007 \pm 0.044$ & $0.035 \pm 0.054$ \\
$\mathrm{IA}$ & $-0.143 \pm 0.134$ & $-0.124 \pm 0.148$ & $0.044 \pm 0.155$ & $0.098 \pm 0.134$ & $0.185 \pm 0.167$ \\
$\mathrm{~A}{ }^{1} \mathrm{~B}$ & $-0.090 \pm 0.059$ & $-0.082 \pm 0.065$ & $-0.016 \pm 0.068$ & $0.064 \pm 0.060$ & $0.074 \pm 0.074$ \\
$\mathrm{~A}^{2} \mathrm{~B}$ & $-0.043 \pm 0.035$ & $-0.016 \pm 0.039$ & $0.003 \pm 0.041$ & $0.090 \pm 0.037^{*}$ & $0.069 \pm 0.045$ \\
$\mathrm{BB}$ & $-0.060 \pm 0.077$ & $-0.051 \pm 0.084$ & $-0.026 \pm 0.088$ & $0.051 \pm 0.078$ & $0.094 \pm 0.095$ \\
$\mathrm{IB}$ & $0.029 \pm 0.068$ & $0.103 \pm 0.075$ & $0.001 \pm 0.078$ & $0.208 \pm 0.069^{* *}$ & $-0.043 \pm 0.085$ \\
\hline
\end{tabular}

${ }^{1}$ All measures were collected in the national milk recording program, and measures of yield and milk content of protein and fat were derived from mid infrared predictions.

$\dagger P<0.10,{ }^{*} P<0.05,{ }^{* *} P<0.01$. 
been associated with milk protein content (Schnabel et al., 2005; Olsen et al., 2007).

Additive and dominance deviations at $B L G$ were not significant $(P>0.05)$ for milk production and protein yield. Similar to results for $\mathrm{CN}$ genes, results for $B L G$ genotype effects on milk production traits are not consistent across studies. Some authors (Lunden et al., 1997; Ojala et al., 1997; Heck et al., 2009) reported no association between $B L G$ genotype and milk production traits, whereas Ikonen et al. (1999b) reported that genotype AA exerted favorable effects on milk and protein yields, and genotype BB was associated with increased milk fat content.

In a study evaluating the effect of genetic merit on protein composition, Bobe et al. (2007) concluded that there were small differences in milk protein composition of cows of different genetic merit for milk yield and that, as a consequence, selective breeding for increased yield is not expected to affect composition of milk protein if selection is carried out for a few generations only.

Estimated genetic correlations between protein yield and concentrations of major milk proteins have been reported to be low or very low, indicating that selection for increased protein yield is expected to exert negligible effects on protein composition (Schopen et al., 2009). Expected outcomes of selection to enhance milk protein content are a small increase in $\kappa$ - $\mathrm{CN}$ percentage and slight decreases in $\alpha_{\mathrm{S}^{-}} \mathrm{CN}$ and $\alpha$-LA percentages, whereas selection for increased milk yield is expected to exert opposite effects on protein composition (Schopen et al., 2009).

\section{Effects of Casein Haplotypes on Protein, Casein, Whey Protein, and Casein Number}

Estimates of CN haplotype effects on PRT, TCN, $\mathrm{WH}$, and casein number are reported in Table 6. Unlike effects on milk production traits, $\mathrm{CN}$ haplotypes exerted significant effects on PRT and TCN content measured by RP-HPLC. Estimated effects on PRT were closely related to those obtained for TCN because these 2 traits were tightly associated (Pearson productmoment $\mathrm{r}=0.99, P<0.001)$. Variation in TCN was ascribed to both CSN2 and CSN3 gene effects. Haplotypes carrying CSN3 B exhibited greater TCN and casein number and no difference in $\mathrm{WH}$ compared with haplotypes carrying CSN3 $\mathrm{A}$. The effect of CSN3 B on TCN was not consistent across haplotypes. As an example, haplotypes $\mathrm{A}^{1} \mathrm{~B}$ and $\mathrm{A}^{1} \mathrm{~A}$ exhibited no significant difference in TCN content. Marked differences in TCN and casein number due to CSN3 variants were observed in association with CSN2 $\mathrm{A}^{2}$ or B. Also, haplotypes carrying CSN2 B showed increased TCN but similar WH compared with haplotypes including other
Table 5. Estimated additive and dominance deviations $( \pm \mathrm{SE})$ at $B L G$ ( $\beta$-LG) locus on milk, protein, and fat daily yield, and fat and protein content (magnitude of deviations is expressed in SD units of traits) ${ }^{1}$

\begin{tabular}{lcc}
\hline Trait $^{2}$ & Additive deviation & Dominance deviation \\
\hline Milk yield & $0.046 \pm 0.023 \dagger$ & $-0.039 \pm 0.032$ \\
Protein yield & $0.045 \pm 0.026 \dagger$ & $-0.034 \pm 0.036$ \\
Fat yield & $0.034 \pm 0.027$ & $-0.025 \pm 0.037$ \\
Protein content & $-0.003 \pm 0.024$ & $0.001 \pm 0.032$ \\
Fat content & $0.004 \pm 0.030$ & $0.038 \pm 0.040$ \\
\hline
\end{tabular}

${ }^{1}$ Additive deviation was computed as $0.5 \times\left(\hat{\beta}_{B L G B B}-\hat{\beta}_{B L G A A}\right)$, where $\hat{\beta}_{B L G B B}$ and $\hat{\beta}_{B L G A A}$ are model solutions for $B L G \mathrm{BB}$ and AA genotypes, respectively; dominance deviation was computed as $\hat{\beta}_{B L G A B}-0.5 \times\left(\hat{\beta}_{B L G B B}+\hat{\beta}_{B L G A A}\right)$, where $\hat{\beta}_{B L G A B}$ is the model solution for $B L G \mathrm{AB}$ genotype.

${ }^{2}$ All measures were collected in the national milk recording program, and measures of yield and milk content of protein and fat were derived from mid infrared predictions.

$\dagger P<0.10$.

CSN2 alleles. Conversely, Bobe et al. (1999) reported no significant effect of milk protein genotypes on total protein content measured by RP-HPLC.

\section{Effects of Casein Haplotypes on Content of Protein Fractions}

Estimated effects of $\mathrm{CN}$ haplotypes on content of milk protein fractions are reported in Table 7. Casein haplotypes had marked effects on content of $\mathrm{CN}$ fractions. In agreement with Hallén et al. (2008), CSN2 and $C S N 3$ alleles affected expression of the $\mathrm{CN}$ fraction that the gene encodes and had limited effects on whey protein fractions. A few studies investigated milk protein composition. Most of those studies considered CN genotype effects (Ng-Kwai-Hang et al., 1987; Bobe et al., 1999; Hallén et al., 2008), whereas only Heck et al. (2009) analyzed effects of CN haplotypes. In that study, only the glyco-free $\kappa$-CN content was assessed because the glycosylated form was not detectable. Coolbear et al. (1996) reported that the amount of glycosylation for $\kappa-\mathrm{CN} B$ is much greater than that for $\kappa-\mathrm{CN} \mathrm{A}$, indicating that the CSN3 B effect on content of $\kappa-\mathrm{CN}$ might have been underestimated in Heck et al. (2009).

In our study, the increased CN content $(P<0.001)$ associated with haplotypes carrying CSN3 $\mathrm{B}$ is exclusively attributable to a significant increase in $\kappa$-CN content, with no variation in content of other $\mathrm{CN}$ fractions. Even though several authors (Van Eenennaam and Medrano, 1991; Robitaille and Petitclerc, 2000; Vachon et al., 2004) have reported allele-specific protein expression for CSN3, others (Ehrmann et al., 1997; Hallén et al., 2008) have found no significant difference in expression between CSN $3 \mathrm{~A}$ and B. Robitaille and Petitclerc (2000) tried to explain these inconsistencies 
Table 6. Estimated effects $( \pm \mathrm{SE})$ of $C S N 2-C S N 3(\beta-\kappa-\mathrm{CN})$ haplotypes compared with haplotype $\mathrm{A}^{2} \mathrm{~A}$ on protein, casein, and whey protein content, and casein number measured by reversed-phase HPLC (magnitude of effects is expressed in SD units of traits $)^{1}$

\begin{tabular}{lcccc}
\hline Haplotype & Protein & Casein & Whey protein & Casein number \\
\hline $\mathrm{A}^{2} \mathrm{~A}$ & 0 & 0 & 0 & 0 \\
$\mathrm{~A}^{1} \mathrm{~A}$ & $-0.063 \pm 0.044$ & $-0.056 \pm 0.044$ & $-0.086 \pm 0.043^{*}$ & $0.056 \pm 0.044$ \\
$\mathrm{BA}$ & $0.354 \pm 0.047^{* * *}$ & $0.401 \pm 0.047^{* * *}$ & $0.009 \pm 0.046$ & $0.467 \pm 0.047^{* * *}$ \\
$\mathrm{IA}$ & $0.183 \pm 0.140$ & $0.223 \pm 0.140$ & $-0.081 \pm 0.137$ & $0.432 \pm 0.138^{*}$ \\
$\mathrm{~A}^{1} \mathrm{~B}$ & $0.009 \pm 0.063$ & $0.034 \pm 0.064$ & $-0.130 \pm 0.063^{*}$ & $0.238 \pm 0.063^{* * *}$ \\
$\mathrm{~A}^{2} \mathrm{~B}$ & $0.219 \pm 0.039^{* * *}$ & $0.252 \pm 0.039^{* * *}$ & $-0.014 \pm 0.038$ & $0.316 \pm 0.038^{* * *}$ \\
$\mathrm{BB}$ & $0.645 \pm 0.081^{* * *}$ & $0.747 \pm 0.082^{* * *}$ & $-0.078 \pm 0.080$ & $0.964 \pm 0.081^{* * *}$ \\
$\mathrm{IB}$ & $0.485 \pm 0.072^{* * *}$ & $0.528 \pm 0.073^{* * *}$ & $0.133 \pm 0.071 \dagger$ & $0.430 \pm 0.072^{* * *}$ \\
\hline
\end{tabular}

${ }^{1}$ Protein $=\alpha_{\mathrm{S}^{1}} \mathrm{CN}+\alpha_{\mathrm{S}^{-}} \mathrm{CN}+\beta-\mathrm{CN}+\gamma-\mathrm{CN}+\kappa_{-} \mathrm{CN}+\beta-\mathrm{LG}+\alpha-\mathrm{LA} ;$ casein $=\alpha_{\mathrm{S}^{-}} \mathrm{CN}+\alpha_{\mathrm{S}^{-}} \mathrm{CN}+\beta-\mathrm{CN}$ $+\gamma-\mathrm{CN}+\kappa-\mathrm{CN}$; whey protein $=\beta-\mathrm{LG}+\alpha$-LA; casein number $=(\mathrm{CN} /$ protein $) \times 100$.

$\dagger P<0.10 ;{ }^{*} P<0.05 ;{ }^{* * *} P<0.001$.

by suggesting that differential expression might arise from effects of polymorphisms located in the noncoding region of the gene.

Allele-specific differential expression was also detected for CSN2. In agreement with previous investigations (Ng-Kwai-Hang et al., 1987; Hallén et al., 2008), CSN2 B had the effect of increasing $\beta$-CN content, and alternative CSN2 alleles had significant effects on the same trait but of smaller magnitude than that exerted by CSN2 B. The increased $\beta-\mathrm{CN}$ content observed for haplotypes carrying CSN2 B was associated with decreased content of $\alpha_{\mathrm{S}_{1}}-\mathrm{CN}$ and, to a lesser extent, of $\mathrm{\alpha}_{\mathrm{S} 2}-\mathrm{CN}$. Effects of CSN2 B were also favorable for $\mathrm{\kappa}-\mathrm{CN}$ content, whereas those on content of $\mathrm{WH}$ were trivial.

Compared with haplotypes carrying CSN2 $\mathrm{A}^{2}$, haplotypes containing CSN2 $\mathrm{A}^{1}$ exhibited lower $\beta$ - and $\alpha_{\mathrm{S}^{-}}$ $\mathrm{CN}$ and greater $\alpha_{\mathrm{S}^{-}}$and $\kappa-\mathrm{CN}$ content. A major effect of CSN2 $\mathrm{A}^{1}$ was a noticeable decrease in $\gamma$-CN content. The effect of CSN2 I has never been estimated in previous studies and its role in the variation of protein composition has never been reported. Results of this study indicate that CSN2 I may exert positive effects on expression of $\beta-\mathrm{CN}$ compared with the most frequent alleles, without altering content of other protein fractions.

Casein haplotypes had small effects on WH. Bobe et al. (1999) reported that $C S N 3 \mathrm{~B}$ did not affect $\alpha-\mathrm{LA}$ concentration, whereas Ng-Kwai-Hang et al. (1987) and Heck et al. (2009) observed a slightly decreased $\alpha$-LA content associated with this allele. In our study, a moderate positive effect of haplotype IB on $\beta-L G$ content was observed, which partially agrees with results obtained by Bobe et al. (1999), who reported a slight increase of $\beta-L G$ to total protein ratio associated with CSN3 B.

\section{Effect of Casein Haplotypes on Protein Composition}

Estimated effects of CN haplotypes on protein composition are reported in Table 8. Several studies (Lunden et al., 1997; Mayer et al., 1997; Robitaille et al., 2002) reported a significant effect of $C S N 3$ alleles on $\kappa-\mathrm{CN}$ to total $\mathrm{CN}$ ratio and a significant association of allele $\mathrm{B}$ with increased $\kappa$-CN percentage. As expected, all haplotypes carrying $C S N 3 \mathrm{~B}$ had positive effects on $\kappa$-CN percentage $(P<0.001)$ compared with those carrying CSN3 A. This result is consistent across studies (Van Eenennaam and Medrano, 1991; Bobe et al., 1999; Heck et al., 2009). Similar to results obtained for content of milk protein fractions, the marked increase of $\kappa$ - $\mathrm{CN}$ percentage associated with CSN3 B occurred at the expense of all other $\mathrm{CN}$ fractions, with the exception of $\beta$-CN. A marked decrease of $\alpha_{S_{1}}$-CN relative content in $\mathrm{CN}$, associated with $C S N 3 \mathrm{~B}$, has been reported in other studies (Bobe et al., 1999; Hallén et al., 2008; Heck et al., 2009). The inverse relationship between $\kappa$-CN percentage and $\alpha_{\mathrm{S}^{1}} \mathrm{CN}$ percentage supports the hypothesis that specific proteins compete for expression in the mammary gland (McClenaghan et al., 1995).

Alleles at CSN2 exhibited different effects on protein composition in magnitude and sign. As an example, haplotypes including CSN2 B were associated with increased $\beta-\mathrm{CN}$ percentage compared with alternative haplotypes. As for content of protein fractions, increased $\beta$-CN percentage associated with haplotypes carrying CSN2 B occurred mostly at the expense of $\alpha_{\mathrm{S1}^{-}} \mathrm{CN}$ and, to a lesser degree, of $\alpha_{\mathrm{S}^{2}} \mathrm{CN}$, with no change in relative content of $\kappa-\mathrm{CN}$.

Contents of $\alpha_{\mathrm{S}^{-}} \mathrm{CN}$ and $\beta-\mathrm{CN}$ in $\mathrm{CN}$ were inversely related (Pearson product-moment $\mathrm{r}=-0.51 ; P<$ 0.001 ), indicating that these proteins undergo a competitive synthesis. Consequently, haplotypes with positive effects on $\beta$-CN percentage exerted negative effects on $\alpha_{\mathrm{S} 1}-\mathrm{CN}$ percentage. Likely, milk proteins, namely $\alpha_{\mathrm{S}^{-}}$and $\beta-\mathrm{CN}$, are co-regulated. According to Bobe et al. (1999), a gene sequence can influence the synthesis of other milk proteins through a limited pool of transcriptional factors, amino acids, or both. Haplotypes carrying CSN2 B were also associated with variation 
of whey protein composition, namely with an increased $\beta$-LG relative content.

In agreement with Heck et al. (2009), haplotypes carrying CSN2 $\mathrm{A}^{1}$ were associated with increased $\alpha_{\mathrm{S} 1}-\mathrm{CN}$ and $\kappa-\mathrm{CN}$ percentages and decreased $\alpha_{\mathrm{S}_{2}}-\mathrm{CN}$ and $\beta-\mathrm{CN}$ percentages relative to haplotypes carrying CSN2 $\mathrm{A}^{2}$. In addition, a marked decrease of $\gamma$-CN percentage was detected for haplotypes carrying CSN2 $\mathrm{A}^{1}$.

The effect of CSN2 I on milk protein composition was very similar to the effect on content of protein fractions and positively affected $\beta-\mathrm{CN}$ percentage relative to allele $\mathrm{A}^{1}$ and $\mathrm{A}^{2}$. Also for CSN2 I, the increase in $\beta-C N$ percentage was associated with a decrease of $\alpha_{\mathrm{S} 1}-\mathrm{CN}$ percentage.

\section{Effect of BLG Genotypes on Content of Protein Fractions and on Protein Composition}

Estimated additive and dominance deviation at $B L G$ for contents of protein, casein, whey protein, and protein fractions and for protein composition are reported in Table 9. Genotypes at $B L G$ exerted significant effects on content of protein fractions and on whey protein composition. Additive deviations were positive for PRT and TCN and negative for $\mathrm{WH}$, indicating that $B L G$ $\mathrm{B}$ was associated $(P<0.001)$ with increased content of $\mathrm{CN}$ and decreased $\mathrm{WH}$. Therefore, $B L G \mathrm{~B}$ also had the effect of increasing casein number $(P<0.001)$. These results agree with those reported by Braunschweig et al. (2000). Hallén et al. (2008) reported a negative association of $B L G$ B with PRT, whereas Bobe et al. (1999) found no effect of $B L G$ genotypes on the same trait. Inconsistencies of results across studies might be attributed, in part, to different breeds and to the limited size of investigated samples used in some studies.

With the exception of $\gamma$-CN, additive deviations at $B L G$ were significant $(P<0.01)$ for content of all milk protein fractions. Significant deviations were positive, indicating that $B L G \mathrm{~B}$ had the effect of increasing the content of milk proteins relative to $B L G \mathrm{~A}$, for all $\mathrm{CN}$ fractions and $\alpha-\mathrm{LA}$ and negative for $\beta-\mathrm{LG}$.

Effects of $B L G$ were trivial for $\mathrm{CN}$ composition, but they were of great magnitude for composition of whey protein. Allele B at $B L G$ was negatively associated $(P<$ 0.001 ) with $\beta$-LG percentage. Previous studies (Wagner et al., 1994; Lum et al., 1997; Folch et al., 1999) attributed the large effect of $B L G$ genotypes on $\beta$-LG content to differences in expression caused by polymorphisms in the gene promoter region, which is physically linked to $B L G$. Differences in stability of mRNA derived from $A$ and B alleles have also been suggested (Heck et al., 2009 ) to explain variation of $\beta-\mathrm{LG}$ content across $B L G$ genotypes. Heck et al. (2009) reported that $B L G$ genotypes accounted for $90 \%$ of genetic variation of $\beta-L G$

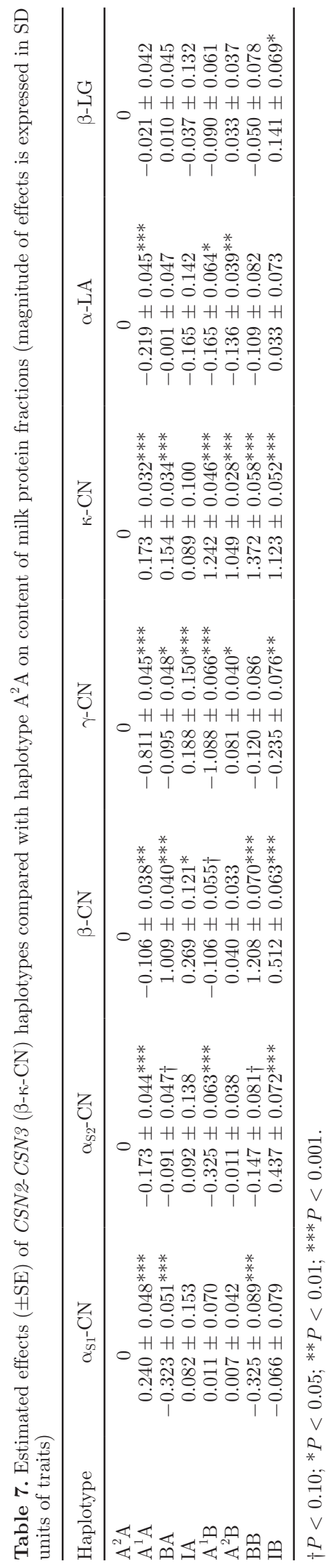

Journal of Dairy Science Vol. 93 No. 8, 2010 
Table 8. Estimated effects $( \pm \mathrm{SE})$ of $C S N 2 C S N 3(\beta-\kappa-\mathrm{CN})$ haplotypes compared with haplotype $\mathrm{A}^{2} \mathrm{~A}$ on composition of casein and of whey protein (magnitude of effects is expressed in SD units of traits) ${ }^{1}$

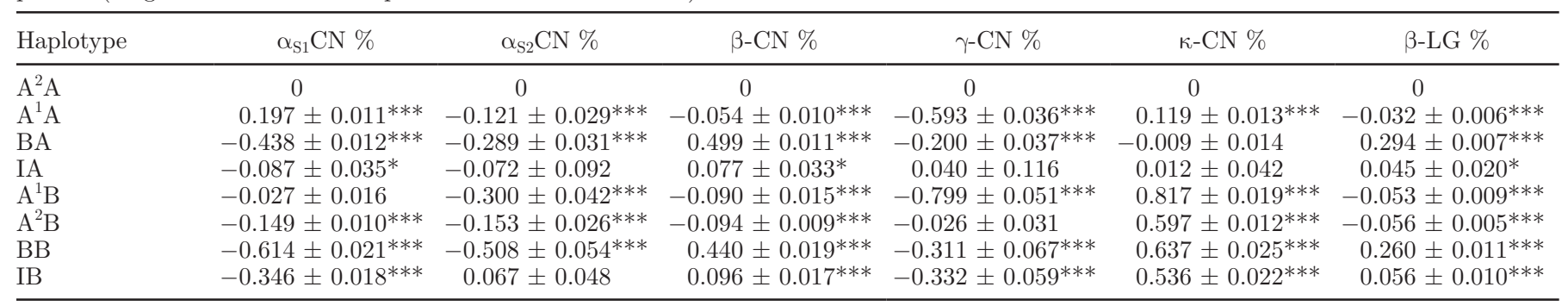

${ }^{1} \alpha_{\mathrm{S}_{1}-\mathrm{CN}} \%, \alpha_{\mathrm{S}^{2}} \mathrm{CN} \%, \beta-\mathrm{CN} \%, \gamma-\mathrm{CN} \%$ and $\kappa$-CN $\%$ are measured as percentages of total casein content; $\beta$-LG $\%$ is measured as percentage of total whey protein content.

$* P<0.05 ; * * * P<0.001$

concentration in milk protein. Likewise, Bobe et al. (1999) concluded that $B L G$ genotypes regulate almost exclusively the proportion of $\beta$-LG in milk protein.

Dominance deviations at $B L G$ were significant $(P<$ $0.001)$ in our study for both content and composition of whey protein whereas they were unimportant for content of $\mathrm{CN}$ fractions and $\mathrm{CN}$ composition.

The effect of $B L G$ genotypes on relative content of individual $\mathrm{CN}$ fractions is less investigated and studies have focused on different breeds, which might partly explain inconsistencies of reported results. In our study, $B L G$ genotypes affected TCN and casein number and had no effect on CN composition. Previous investigations (Ng-Kwai-Hang et al., 1987; Heck et al., 2009) reported that the increased relative concentration of $\beta$-LG in milk protein associated with $B L G \mathrm{~A}$ was counterbalanced by a decreased relative content of all other fractions, particularly $\beta-\mathrm{CN}$ and $\alpha_{\mathrm{S}_{1}-\mathrm{CN}}$. Likewise, Bobe et al. (1999) concluded that $B L G$ A increased the proportion of $\beta$-LG and decreased relative content of $\alpha_{\mathrm{S} 1}-\mathrm{CN}$ and $\beta-\mathrm{CN}$ in milk protein. These results were partly expected because, in those studies, relative content of $\mathrm{CN}$ fractions was expressed as a percentage of each $\mathrm{CN}$ fraction to total milk protein, and variation

Table 9. Estimated additive and dominance deviations $( \pm \mathrm{SE})$ at $B L G(\beta-\mathrm{LG})$ locus for protein, casein, and whey protein content, casein number, protein fractions content, and protein composition measured by reversedphase HPLC (magnitude of deviations is expressed in SD units of traits) ${ }^{1}$

\begin{tabular}{|c|c|c|}
\hline Trait $^{2}$ & Additive deviation & Dominance deviation \\
\hline \multicolumn{3}{|l|}{ Content } \\
\hline Protein & $0.095 \pm 0.026^{* * *}$ & $-0.010 \pm 0.034$ \\
\hline Casein & $0.157 \pm 0.026^{* * *}$ & $-0.026 \pm 0.034$ \\
\hline Whey protein & $-0.270 \pm 0.026^{* * *}$ & $0.082 \pm 0.033^{*}$ \\
\hline Casein number & $0.591 \pm 0.026^{* * *}$ & $-0.149 \pm 0.034^{* * *}$ \\
\hline \multicolumn{3}{|l|}{ Protein fractions content } \\
\hline$\alpha_{\mathrm{S}^{-}} \mathrm{CN}$ & $0.180 \pm 0.028^{* * *}$ & $-0.023 \pm 0.037$ \\
\hline$\alpha_{\mathrm{S} 2}-\mathrm{CN}$ & $0.070 \pm 0.026^{* *}$ & $0.006 \pm 0.034$ \\
\hline$\beta-\mathrm{CN}$ & $0.114 \pm 0.022^{* * *}$ & $-0.041 \pm 0.029$ \\
\hline$\gamma-\mathrm{CN}$ & $0.038 \pm 0.026$ & $0.054 \pm 0.036$ \\
\hline$\kappa-\mathrm{CN}$ & $0.094 \pm 0.019^{* * *}$ & $-0.022 \pm 0.024$ \\
\hline$\alpha-\mathrm{LA}$ & $0.172 \pm 0.026^{* * *}$ & $-0.191 \pm 0.034^{* * *}$ \\
\hline$\beta-\mathrm{LG}$ & $-0.382 \pm 0.025^{* * *}$ & $0.166 \pm 0.032^{* * *}$ \\
\hline \multicolumn{3}{|l|}{ Protein composition } \\
\hline$\alpha_{S 1}-\mathrm{CN}, \%$ of total casein & $0.036 \pm 0.017^{*}$ & $0.002 \pm 0.023$ \\
\hline$\alpha_{\mathrm{S} 2}-\mathrm{CN}, \%$ of total casein & $-0.047 \pm 0.028 \dagger$ & $0.029 \pm 0.036$ \\
\hline$\beta-\mathrm{CN}, \%$ of total casein & $-0.008 \pm 0.018$ & $-0.047 \pm 0.023^{*}$ \\
\hline$\gamma-\mathrm{CN}, \%$ of total casein & $-0.027 \pm 0.027$ & $0.061 \pm 0.037 \dagger$ \\
\hline k-CN, \% of total casein & $0.023 \pm 0.015$ & $-0.001 \pm 0.020$ \\
\hline$\beta$-LG, $\%$ of total whey protein & $-0.520 \pm 0.024^{* * *}$ & $0.349 \pm 0.032^{* * *}$ \\
\hline
\end{tabular}

${ }^{1}$ Additive deviation was computed as $0.5 \times\left(\hat{\beta}_{B L G B B}-\hat{\beta}_{B L G A A}\right)$, where $\hat{\beta}_{B L G B B}$ and $\hat{\beta}_{B L G A A}$ are model solutions for $B L G \mathrm{BB}$ and $\mathrm{AA}$ genotypes, respectively; dominance deviation was computed as $\hat{\beta}_{B L G A B}-0.5 \times\left(\hat{\beta}_{B L G B B}+\hat{\beta}_{B L G A A}\right)$, where $\hat{\beta}_{B L G A B}$ is the model solution for $B L G$ AB genotype.

${ }^{2}$ Casein $=\alpha_{\mathrm{S}^{-}} \mathrm{CN}+\alpha_{\mathrm{S}_{2}} \mathrm{CN}+\beta-\mathrm{CN}+\gamma-\mathrm{CN}+\kappa-\mathrm{CN}$; whey protein $=\beta-\mathrm{LG}+\alpha-\mathrm{LA}$; protein $=\mathrm{CN}+$ whey protein; casein number $=(\mathrm{CN} /$ protein $) \times 100$.

$\dagger P<0.10 ;{ }^{*} P<0.05 ;{ }^{* *} P<0.01 ; * * * P<0.001$. 
of $\mathrm{CN}$ and whey protein content associated with $B L G$ genotypes was large. Mechanisms causing the effect of $B L G$ locus relative content of $\mathrm{CN}$ fractions are currently unknown.

Based on our results, breeding practices aimed to increase the frequency of $B L G$ B in the Simmental cattle population are expected to affect the composition of whey protein and to increase $\mathrm{CN}$ content with trivial effects on $\mathrm{CN}$ composition. As discussed by Heck et al. (2009), a lack of change in CN composition ensures that selection for increasing the frequency of $B L G$ $\mathrm{B}$ does not affect cheese quality and is beneficial for increasing cheese yield with no unfavorable effect on cheese properties.

\section{Contribution of Additive Genetic Variance to Total Variance of Protein Fraction Contents}

Estimates of additive genetic variances (data not shown) indicate that the polygenic background of the cow affects variation of protein fraction contents, even when effects of $\mathrm{CN}$ haplotypes and $B L G$ genotypes are accounted for in the statistical model. Estimated additive genetic variance was 38 and $39 \%$ of total variance for $\alpha_{\mathrm{S} 2}-\mathrm{CN}$ and $\beta-\mathrm{LG}$ content, respectively. The effect of the sire of the cow on variation of $\gamma-\mathrm{CN}$ content was trivial, and ratios of additive genetic variance to total variance observed for $\beta-\mathrm{CN}$ and $\alpha-\mathrm{LA}$ content were moderate, ranging from 14 to $16 \%$. For all other protein fractions, the ratio of additive genetic variance to total variance estimated for protein content ranged from 21 to $32 \%$. Results for protein composition were similar to those obtained for protein content. Although genetic variation of protein fraction contents and protein composition is greatly attributable to effects of $\mathrm{CN}$ haplotypes and $B L G$ genotypes, the role of the polygenic background of the animal is noteworthy. Besides milk protein genes, other loci are then responsible for variation of protein fractions content and protein composition. Estimation of genetic parameters for these traits will be the objective of future investigations.

\section{CONCLUSIONS}

Our results indicate that CSN2-CSN3 haplotypes and $B L G$ genotypes play an important role in variation of milk protein fraction contents and milk protein composition. This suggests that increasing the frequency of specific genotypes or haplotypes might be an effective way to alter milk protein composition. The marked effects of CN haplotypes and $B L G$ genotypes on protein composition, together with the lack of effects on milk production traits, ensure that altering milk protein composition does not interfere with yield traits. In ad- dition to milk protein loci, polygenes affect phenotypic variation of concentrations of milk protein fractions and their relative content in total milk protein. Genetic variation of protein composition might be exploited in breeding programs aimed to enhance milk renneting properties and cheese yield or to obtain milk with increased content of specific protein fractions. Currently, knowledge concerning the effects of milk protein composition, CN haplotypes, and $B L G$ genotypes on technological properties of milk, as well as availability of estimated genetic parameters for protein composition, is scarce and requires further investigation.

\section{ACKNOWLEDGMENTS}

The authors thank ANAPRI (Udine, Italy) for providing pedigree information as well as AAFVG (Codroipo, Italy) and the milk recording agencies of Treviso, Vicenza, and Padova for the organization of herd sampling. Alessandra Stella (CERSA-Fondazione Parco Tecnologico Padano, Segrate, Milan, Italy) is gratefully acknowledged for having provided the software for computation of haplotype probabilities. Financial support by Regione del Veneto (Azione Biotech III Bis, Delibera CIPE no. 03, 03/22/2006) and the University of Padova (CPDA067387) is also gratefully acknowledged.

\section{REFERENCES}

Aleandri, R., G. Buttazzoni, J. C. Schneider, A. Caroli, and R. Davoli. 1990. The effects of milk protein polymorphisms on milk components and cheese-producing ability. J. Dairy Sci. 73:241255.

Amigo, L., P. J. Martin-Alvarez, E. Garcia-Muro, and I. Zarazaga. 2001. Effect of milk protein haplotypes on the composition and technological properties of Fleckvieh bovine milk. Milchwissenschaft $56: 488-491$.

Bobe, G., D. C. Beitz, A. E. Freeman, and G. L. Lindberg. 1999. Effect of milk protein genotypes on milk protein composition and its genetic parameter estimates. J. Dairy Sci. 82:2797-2804.

Bobe, G., G. L. Lindberg, A. E. Freeman, and D. C. Beitz. 2007. Short communication: Composition of milk protein and milk fatty acids is stable for cows differing in genetic merit for milk production. J. Dairy Sci. 90:3955-3960.

Boettcher, P. J., A. Caroli, A. Stella, S. Chessa, E. Budelli, F. Canavesi, S. Ghiroldi, and G. Pagnacco. 2004a. Effects of casein haplotypes on milk production traits in Italian Holstein and Brown Swiss cattle. J. Dairy Sci. 87:4311-4317.

Boettcher, P. J., G. Pagnacco, and A. Stella. 2004b. A Monte Carlo approach for estimation of haplotype probabilities in half-sib families. J. Dairy Sci. 87:4303-4310.

Bonfatti, V., L. Grigoletto, A. Cecchinato, L. Gallo, and P. Carnier. 2008. Validation of a new reversed-phase high-performance liquid chromatography method for separation and identification of bovine milk protein genetic variants. J. Chromatogr. A 1195:101-106.

Bovenhuis, H., J. A. M. van Arendonk, and S. Korver. 1992. Associations between milk protein polymorphisms and milk production traits. J. Dairy Sci. 75:2549-2559.

Braunschweig, M., C. Hagger, G. Stranzinger, and Z. Puhan. 2000. Associations between casein haplotypes and milk production traits of Swiss Brown cattle. J. Dairy Sci. 83:1387-1395. 
Caroli, A. M., S. Chessa, and G. J. Erhardt. 2009. Invited review: Milk protein polymorphisms in cattle: Effect on animal breeding and human nutrition. J. Dairy Sci. 92:5335-5352.

Coolbear, K. P., D. F. Elgar, and J. S. Ayers. 1996. Profiling of genetic variants of bovine kappa-casein macropeptide by electrophoretic and chromatographic techniques. Int. Dairy J. 6:1055-1068.

Ehrmann, S., H. Bartenschlager, and H. Gendermann. 1997. Quantification of gene effects on single milk proteins in selected groups of dairy cows. J. Anim. Breed. Genet. 114:49-53.

Ferretti, L., P. Leone, and V. Sgaramella. 1990. Long range restriction analysis of the bovine casein genes. Nucleic Acids Res. 18:68296833.

Folch, J. M., P. Dovc, and J. F. Medrano. 1999. Differential expression of bovine beta-lactoglobulin A and B promoter variants in transiently transfected HC11 cells. J. Dairy Res. 66:537-544.

Graml, R., and F. Pirchner. 2003. Effects of milk protein loci on content of their proteins. Arch. Tierzucht. Dummerstorf 46:331-340.

Hallén, E., A. Wedholm, A. Andrén, and A. Lundén. 2008. Effect of $\beta$-casein, $\kappa$-casein and $\beta$-lactoglobulin genotypes on concentration of milk protein variants. J. Anim. Breed. Genet. 17:791-799.

Heck, J. M. L., A. Schennink, H. J. F. van Valenberg, H. Bovenhuis, M. H. P. W. Visker, J. A. M. van Arendonk, and A. C. M. van Hooijdonk. 2009. Effects of milk protein variants on the protein composition of bovine milk. J. Dairy Sci. 92:1192-1202.

Hill, W. G., and A. Robertson. 1968. Linkage disequilibrium in finite populations. Theor. Appl. Genet. 38:226-231.

Ikonen, T., K. Ahlfors, R. Kempe, M. Ojala, and O. Ruottinen 1999a. Genetic parameters for the milk coagulation properties and prevalence of noncoagulating milk in Finnish dairy cows. J. Dairy Sci. 82:205-214.

Ikonen, T., H. Bovenhuis, M. Ojala, O. Ruottinen, and M. Georges. 2001. Associations between casein haplotypes and first lactation milk production traits in Finnish Ayrshire cows. J. Dairy Sci 84:507-514.

Ikonen, T., M. Ojala, and O. Ruottinen. 1999b. Associations between milk protein polymorphism and first lactation milk production traits in Finnish Ayrshire cows. J. Dairy Sci. 82:1026-1033.

Jann, O. C., E. M. Ibeagha-Awemu, C. Ozbeyaz, P. Zaragoza, J. L. Williams, P. Ajmone-Marsan, J. A. Lenstra, K. MoazamiGoudarzi, and G. Erhardt. 2004. Geographic distribution of haplotype diversity at the bovine casein locus. Genet. Sel. Evol. $36: 243-257$.

Jõudo, I., M. Henno, T. Kaart, T. Püssa, and O. Kärt. 2008. The effect of milk protein contents on the rennet coagulation properties of milk from individual dairy cows. Int. Dairy J. 18:964-967.

Kennedy, B. W., M. Quinton, and J. A. van Arendonk. 1992. Estimation of effects of single genes on quantitative traits. J. Anim. Sci. 70:2000-2012.

Lien, S., L. Gomez-Raya, T. Steine, E. Fimland, and S. Rogne. 1995. Associations between casein haplotypes and milk yield traits. J. Dairy Sci. 78:2047-2056.

Lum, L. S., P. Dovc, and J. F. Medrano. 1997. Polymorphisms of bovine beta-lactoglobulin promoter and differences in the binding affinity of activator protein-2 transcription factor. J. Dairy Sci. 80:1389-1397.

Lunden, A., M. Nilsson, and L. Janson. 1997. Marked effect of betalactoglobulin polymorphism on the ratio of casein to total protein in milk. J. Dairy Sci. 80:2996-3005.

Martin, P., M. Szymanowska, L. Zwierzchowski, and C. Leroux. 2002 The impact of genetic polymorphisms on the protein composition of ruminant milks. Reprod. Nutr. Dev. 42:433-459.

Matějíček, A., J. Matějíčková, M. Štípková, O. Hanuš, V. Genčurová, J. Kysel'ová, E. Němcová, T. Kott, J. Sefrová, M. Krejčová, S. Melčová, I. Hölzelová, J. Bouška, and J. Frelich. 2008. Joint effects of CSN3 and LGB genes on milk quality and coagulation properties in Czech Fleckvieh. Czech J. Anim. Sci. 53:246-252.
Mayer, H. K., M. Ortner, E. Tschager, and W. Ginzinger. 1997 Composite milk protein phenotypes in relation to composition and cheesemaking properties of milk. Int. Dairy J. 7:305-310.

McClenaghan, M., A. Springbett, R. M. Wallace, C. J. Wilde, and A. J. Clark. 1995. Secretory proteins compete for production in the mammary gland of transgenic mice. Biochem. J. 310:637-641.

Ng-Kwai-Hang, K. F., J. F. Hayes, J. E. Moxley, and H. G. Monardes, 1987. Variation in milk protein concentrations associated with genetic polymorphism and environmental factors. J. Dairy Sci 70:563-570.

Ojala, M., T. R. Famula, and J. F. Medrano. 1997. Effects of milk protein genotypes on the variation for milk production traits of Holstein and Jersey cows in California. J. Dairy Sci. 80:17761785

Olsen, H. G., H. Nilsen, B. Hayes, P. R. Berg, M. Svendsen, S. Lien, and T. Meuwissen. 2007. Genetic support for a quantitative trait nucleotide in the $A B C G 2$ gene affecting milk composition of dairy cattle. BMC Genet. 8:32-40.

Pérez-Rodriguez, M. L., P. J. Martin-Alvarez, M. Ramos, E. GarcíaMuro, I. Zarazaga, and L. Amigo. 1998. Genetic polymorphism of bovine milk proteins in Holstein-Friesian and Fleckvieh breeds exploited in Spain. Milchwissenschaft 53:543-546.

Robitaille, G., M. Britten, J. Morisset, and D. Petitclerc. 2002 Quantitative analysis of beta-lactoglobulin A and B genetic variants in milk of cows beta-lactoglobulin $\mathrm{AB}$ throughout lactation. J. Dairy Res. 69:651-654.

Robitaille, G., and D. Petitclerc. 2000. Expression polymorphism of $\kappa$-casein gene in Holstein cows. J. Dairy Res. 67:107-111.

Schaar, J. 1984. Effects of $\kappa$-casein genetic variants and lactation number on the renneting properties of individual milks. J. Dairy Res. 51:397-406.

Schaar, J., B. Hansson, and H. E. Pettersson. 1985. Effects of genetic variants of $\kappa$-casein and $\beta$-lactoglobulin on cheesemaking. J. Dairy Res. 52:429-437.

Schnabel, R. D., J.-J. Kim, M. S. Ashwell, T. S. Sonstegard, C. P. Van Tassell, E. E. Connor, and J. F. Taylor. 2005. Fine-mapping milk production quantitative trait loci on BTA6: Analysis of the bovine osteopontin gene. Proc. Natl. Acad. Sci. USA 102:6896-6901.

Schopen, G. C. B., J. M. L. Heck, H. Bovenhuis, M. H. P. W. Visker, H. J. F. van Valenberg, and J. A. M. van Arendonk. 2009. Genetic parameters for major milk proteins in Dutch Holstein-Friesians. J. Dairy Sci. 92:1182-1191.

Threadgill, D. W., and J. E. Womack. 1990. Genomic analysis of the major bovine milk protein gene. Nucleic Acids Res. 18:69356942 .

Vachon, D., M. Britten, J. Morisset, D. Petitclerc, and G. Robitaille. 2004. Differential allele-specific accumulation of bovine kappacasein mRNA throughout lactation. J. Dairy Res. 71:405-408.

Van Eenennaam, A. L., and J. F. Medrano. 1991. Differences in allelic protein expression in the milk of heterozygous kappa-casein cows. J. Dairy Sci. 74:1491-1496.

Wagner, V. A., T. A. Schild, and H. Geldermann. 1994. DNA variant within the 5 '-flanking region of milk-protein-encoding genes. II. The beta-lactoglobin-encoding gene. Theor. Appl. Genet. 89:121126.

Wedholm, A., L. B. Larsen, H. Lindmark-Månsson, A. H. Karlsson, and A. Andrén. 2006. Effect of protein composition on the cheesemaking properties of milk from individual dairy cows. J. Dairy Sci. 89:3296-3305.

Zhao, H., D. Nettleton, M. Soller, and J. C. M. Dekkers. 2005 Evaluation of linkage disequilibrium measures between multiallelic markers as predictors of linkage disequilibrium between markers and QTL. Genet. Res. 86:77-87. 